\title{
"That's a good question": University researchers' views on ownership and retention of human genetic specimens
}

\author{
R. Jean Cadigan, $P h D^{I}$, Michele M. Easter, PhD , Allison W. Dobson, PhD, JD ${ }^{3}$, Arlene M. Davis, $J D^{I}$, \\ Barbra B. Rothschild, $M D^{l}$, Catherine Zimmer, $P h D^{2,4}$, Rene Sterling, $P h D, M H A^{3}$, \\ and Gail Henderson, $P h D^{I}$
}

Purpose: To explore the views of university-based investigators conducting genetic research with human specimens regarding ownership and retention of specimens, and knowledge of related institutional review board and university policies. Methods: Data were collected in three phases: a qualitative pilot study of 14 investigators; a web-based survey taken by 80 investigators; and follow-up, in-depth interviews with 12 survey respondents. Results: Investigators named a variety of single or multiple owners of human specimens and often expressed confusion regarding specimen ownership. Most associated ownership with rights to control, and responsibilities to maintain, specimens. Investigators viewed specimens as "precious" resources whose value could be increased through long-term or infinite retention, particularly in light of anticipated technological advances in genome science. Their views on ownership and retention were shaped by perceptions of institutional review board policies as immortalized in subject informed consent documents, rather than knowledge of actual policies. Conclusion: Long-term retention of human specimens makes confusion about ownership particularly problematic. Given findings that investigators' views on ownership and retention are largely guided by their perception of university policies, the need for clear, consistent policies at the institution level is urgent. Genet Med 2011: 13(6):569-575.

Key Words: ownership of human specimens, genetic researchers, biobanking, empirical research

$\mathrm{M}$ llions of human biological specimens are acquired and stored in the United States each year for research purposes. ${ }^{1}$ This impetus to acquire and store specimens for long periods of time, sometimes indefinitely, for future research use raises questions about control and ownership of the samples. In addition, the Bayh-Dole Act of 1980 permitted universities to financially benefit from federally funded research and, thus, imbued biologic specimens collected for scientific purposes with potential economic value. Once specimens are perceived as scientifically and economically valuable, interest grows in their ownership.

From the Departments of ${ }^{1}$ Social Medicine and ${ }^{2}$ Sociology, ${ }^{3}$ Center for Genomics and Society, ${ }^{4}$ Odum Institute, University of North Carolina, Chapel Hill; and ${ }^{5}$ Institute for Genome Sciences \& Policy, Center for Genome Ethics, Law \& Policy, Duke University, Durham, North Carolina.

R. Jean Cadigan, PhD, Department of Social Medicine, CB \#7240, University of North Carolina, Chapel Hill, NC 27599-7240. E-mail: jean_cadigan@med.unc.edu.

Disclosure: The authors declare no conflict of interest.

Submitted for publication November 5, 2010.

Accepted for publication January 21, 2011

Published online ahead of print March 30, 2011

DOI: $10.1097 /$ GIM.0b013e318211a9c2
Property law provides the conventional legal construct for ownership, permitting owners to use their property as they see fit (save some agreed-upon prohibitions intended to protect others). Once ownership is recognized, rights and responsibilities related to the property can be established. However, apart from the federal regulations protecting human subjects and exempting from protection some deidentified samples, ${ }^{2}$ little national or state law oversees the creation and use of specimen collections retained for research use for long periods of time (hereafter "biobanks"). Instead, researchers and institutions across the country develop biobanking practices and address concerns with little unifying guidance. As a result, attention is drawn to specimen ownership only when controversy arises, such as when a researcher wishes to move "his" collection to another university ${ }^{3}$ or when a bewildered family learns that their long-dead loved one "lives on" in an immortal cell line (HeLa) created without their knowledge. ${ }^{4}$

Given scant guidance, scholars and policy makers have turned to court opinions to understand how control and ownership of collected samples may inform their use in research. ${ }^{5} \mathrm{~A}$ small collection of case law has determined that samples are controlled and owned not by those who contributed them but by researchers or their institutions. ${ }^{6-8}$ The cases of Moore v. Regents of the University of California and Greenberg v. Miami Children's Hospital denied specimen contributors intellectual property rights in developments that stem from uses of their samples. Washington University v. Catalona used the frame of institutional ownership to prohibit the researcher from moving the collection to another institution and denied subjects some aspects of control over their individual specimens in finding no right for them to have their specimens transferred to another institution. Taken together, the cases do not offer clear guidance; they are consistent only in their denial of a right claimed by individuals who contributed samples. In a more recent case, ${ }^{9,10}$ favorable terms of settlement for tissue contributors may signal a change in how subject rights are framed and protected. However, at this time, investigators and institutions interested in specimen collections conduct their research in an uncertain policy environment. ${ }^{5}$

The ethics literature on biobanking has identified ownership as an important issue, ${ }^{11}$ but despite researchers' central role in collection and storage, their views and practices regarding ownership and long-term retention of specimens have rarely been examined empirically. Only Capron and colleagues ${ }^{12}$ have directly explored researchers' views of ownership of genetic samples and data. Using hypothetical scenarios, 42 international experts engaged in operating, policy making, or conducting research using a biobank were surveyed and found to have "highly divergent and somewhat confused" views. ${ }^{12}$ Nonresearchers' perceptions of ownership are beginning to be explored, including those of people whose samples are used in 
research ${ }^{13}$ and institutional review board (IRB) chairs. ${ }^{14}$ Quite a number of people have written nonempirical articles on ownership. ${ }^{5,15-24}$

In this study, we report on three interrelated studies of university investigators who conduct genetic research on human specimens, examining their perceptions of specimen ownership, their intentions regarding retention of specimens after study completion, and their knowledge of institutional policies related to ownership and retention. This study contributes to an emerging empirical literature on researchers' perceptions related to ethics in research on human biological specimens and biobanking.

\section{MATERIALS AND METHODS}

\section{Overview}

We collected data in three phases (Fig. 1). We began with (1) a qualitative pilot study of researchers' perceptions of ownership of genetic samples conducted in 2006 by several of the authors. Using findings from these interviews, along with an extensive review of the literature on the ethical, legal, and social implications of biobanking, we developed and fielded (2) a web-based survey in 2009 with a larger sample for quantitative analysis. To further explore findings from the web survey, we conducted (3) follow-up interviews with a subset of survey respondents in 2010. All study segments were approved by a university IRB. Verbal consent was obtained from all participants in both the pilot interviews and the follow-up interviews; written consent was waived for the web survey.

\section{Participants}

All participants were engaged in genetic research using human specimens at a large southeastern university; although some participants were geneticists, many were from other scientific disciplines. Potential participants in the initial qualitative study on perceptions of ownership (Pilot Interviews) were identified through the National Institutes of Health CRISP database and University department websites as principal investigators on grants for which they collected human specimens for DNA analysis, and these participants were recruited for the study through a personal email.

Participants in the anonymous web-based survey were recruited by an email to a listserv for all University faculty. As is typical for listserv-based recruitment, we do not know the number of people who received the email; and in the case of this survey, it is impossible to know the total number of researchers engaged in human genetic studies. One hundred ninety-eight researchers entered the web survey. Of these, 102 screened ineligible because they answered "no" to the first question: "Have you ever conducted genetic research using human spec-

Perceptions of Ownership [Pilot Interviews]: Initial explorations Semi-structured interviews $(\mathrm{n}=14)$ analyzed qualitatively.

$\square$

Survey of Investigators [Web Survey]: A broader view of the terrain Web-based survey $(\mathrm{n}=80)$ analyzed quantitatively.

\section{$\square$}

Follow-up interviews with investigators [Follow-up Interviews] Focus on specific topics from the survey results

Semi-structured interviews with survey respondents $(n=12)$ analyzed qualitatively.

Fig. 1. Overview of methods and data. imens, at [University] or elsewhere?" An additional 16 were dropped because of substantial missing data. A total of 80 respondents completed the survey.

Twenty-six of the 80 who completed the web-based survey provided their contact information indicating they were willing to be recontacted for a follow-up interview. Twelve completed an interview; the other 14 were lost to follow-up or declined.

\section{Procedures}

Data for the pilot study were collected during June to October 2006. The web survey was accessible and data were collected from April to June 2009, and the follow-up interviews were conducted from February to April 2010.

Most interviews for the pilot study and follow-up interviews to the web survey were conducted in person; four were conducted by telephone to accommodate respondents. Interviews were conducted by individual coauthors, lasted about 45 minutes, and were digitally recorded and transcribed. The webbased survey was developed and fielded using Qualtrics software $^{25}$ and pilot tested to ensure functionality. Data from eligible respondents were transferred to Stata $10^{26}$ to facilitate data management and analysis.

\section{Measures}

The pilot interviews explored investigators' experiences conducting research studies (with particular emphasis on their currently funded studies), how and under what circumstances investigators gain access to specimens and related data, and the rights and responsibilities of diverse stakeholders. Questions about ownership also included experiences sharing and loaning specimens and views on what would happen if respondents were to leave the University or leave science. Investigators were also asked about their understanding of policies governing specimen use.

The web-based survey examined beliefs and practices related to biospecimen storage and use with a larger sample of investigators. The survey asked respondents to consider one genetic research study they were currently conducting or had conducted in the past. Survey questions addressed the samples used in that focal study, including queries about the number of specimens, how they were acquired, where and for how long they were stored and investigators' perceptions of who owned the specimens and data; the survey also gathered background information about the respondents.

The follow-up interviews explored findings from the web survey by examining three topics in detail. Again focusing on their experiences with one study, respondents were asked to describe underlying decision-making processes regarding retention; to consider the meaning of ownership and under what circumstances it might matter; and to address any external policies that could affect ownership or retention of specimens.

\section{Data analysis}

Data analysis took place in three stages, corresponding to the three phases of this project. First, using conventional content analysis, ${ }^{27}$ four of the authors examined all pilot study transcripts and through an iterative, collaborative process, developed codes to capture segments of the text pertaining to how investigators view the specimens, their perceptions of ownership of the specimens, and their understanding of policies related to the specimens. Second, results from the web survey were analyzed using simple descriptive statistics. Finally, follow-up interview transcripts were analyzed using conventional content analysis, ${ }^{27}$ led by the first author, who had also participated in analysis of the pilot study interviews. The first author 
read each transcript multiple times, kept written notes to record new insights and questions, and debriefed with coauthors about early findings. The first author tagged material relevant to broad coding categories (ownership, storage, and policy) throughout the interview, then coded for subtopics relevant to research questions (e.g., for ownership of samples: who owns, what it means to own). All findings were discussed with coauthors familiar with pilot interviews, web survey, or follow-up interviews, and coding was refined in an iterative process.

\section{RESULTS}

\section{Participant characteristics}

Table 1 presents data on participants within each study. Although all participants in the follow-up interviews were nec-

Table 1 Participant characteristics within each study

\begin{tabular}{lccc}
\hline & $\begin{array}{c}\text { Pilot } \\
\text { interviews (\%) }\end{array}$ & $\begin{array}{c}\text { Web } \\
\text { survey (\%) }\end{array}$ & $\begin{array}{c}\text { Follow-up } \\
\text { interviews }(\%)\end{array}$ \\
\hline Highest degree & $7(50.00)$ & $21(26.25)$ & $4(33.33)$ \\
MD & $5(35.71)$ & $38(47.50)$ & $7(58.33)$ \\
$\mathrm{PhD}$ & $2(14.29)$ & $3(3.75)$ & $1(8.33)$ \\
MD-PhD & $0(0.00)$ & $9(11.25)$ & $0(0.00)$ \\
Other $^{a}$ & $0(0.00)$ & $9(11.25)$ & $0(0.00)$ \\
Missing & & & \\
Role in study & & & \\
PI/Co-PI & $14(100.00)^{c}$ & $33(41.25)$ & $9(75.00)$ \\
$\begin{array}{l}\text { Coinvestigator } \\
\text { Other team } \\
\text { member }\end{array}$ & $0(0.00)$ & $21(26.25)$ & $3(25.00)$ \\
Other role & $0(0.00)$ & $18(22.50)$ & $0(0.00)$ \\
& $0(0.00)$ & $8(10.00)$ & $0(0.00)$
\end{tabular}

Affiliation

\begin{tabular}{|c|c|c|c|}
\hline Medicine & (Not asked) & $48(60.00)$ & $7(58.33)$ \\
\hline Dentistry & & $5(6.25)$ & $3(25.00)$ \\
\hline Public health & & $8(10.00)$ & $1(8.33)$ \\
\hline Other/unspecified & & $9(11.25)$ & $1(8.33)$ \\
\hline Missing & & $10(1.25)$ & $0(0.00)$ \\
\hline
\end{tabular}

Database size (number of individual donors)

$\begin{array}{lccc}1-100 \text { donors } & \text { (Not asked) } & 25(31.25) & 3(25.00) \\ 101-1000 \text { donors } & & 22(27.50) & 1(8.33) \\ 1001-5000 \text { donors } & & 15(18.75) & 5(41.67) \\ >5000 \text { donors } & 3(3.75) & 2(16.67) \\ \text { Missing } & & 15(18.75) & 1(8.33) \\ \text { Total } & 14(100.00) & 80(100.00) & 12(100.00)\end{array}$

The values are represented as frequency (\%). Percentages may not total to 100 due to rounding.

a"Other" degree included RN, MS, MPH, and BS.

${ }^{b}$ Or role with greatest responsibility for the study when more than one role is mentioned.

${ }^{c}$ Participants in the pilot interviews were all PIs since the sample was taken from the CRISP database.

PI, Principal Investigator. essarily participants in the web survey, we do not know whether any of the participants in the pilot interviews also participated in the anonymous web survey. The majority of all respondents held $\mathrm{MD}$ or $\mathrm{PhD}$ degrees, or both. Database size reflected different stages and methods of data acquisition, ranging from 4 to 185,000 specimens from individual donors. The distribution was positively skewed with a few very large databases; the average was 3,985 and the median $250(n=65)$.

\section{Ownership}

\section{Uncertainty and lack of consensus about ownership}

In the pilot interviews, investigators described four partiesthe investigator, the funder, the University, and the specimen contributor-as having ownership or an ownership-related right, although investigators named themselves most often. In some cases, ideas of ownership were informed by an intuitive, proprietary sense of individualized ownership, crystallized by investigator comments such as "I assume I would take my samples with me if I left the University" and "I'm sure the University couldn't sell my samples."

Uncertainty about ownership was also apparent when investigators identified a single owner and then added others as they formulated their responses:

"Who owns the samples? That's a good question. If somebody told me they wanted them back, I would probably give them to them. So, in some sense I suppose they're on loan from the body I got them from. Unless they're dead. I mean otherwise I think, short of that I guess, I would be the next in line of ownership."

Herein, the investigator perceives the sample contributor as holding the primary ownership claim. However, when asked later in the interview, "Does it mean you own [the sample] if you can loan it?" the same investigator offered a different view: "Well, I can loan it. Yeah. I think that I own it pretty much. I am the ultimate authority determining the fate of those entities of data and biological samples." Uncertainty was evident not only from this respondent's suggestion that both investigators and specimen contributors have claims of ownership but also because taken together, the respondent's answers demonstrate a conflict as to whether and how one claim might subordinate another.

Even with the limitations of the small sample size of the pilot interview study, it was striking that something as essential as the ownership of human specimens was understood differently by these researchers. How widespread was this apparent uncertainty about ownership? Was it common to perceive multiple owners for their specimen collections? To investigate these issues further, we included a question about ownership of specimens in our web survey of the larger sample at the same university (Fig. 2).

Survey results confirm the finding from the pilot interviews regarding confusion about ownership. Table 2 presents results from the web survey and the follow-up interviews. Half of survey respondents identified single owners for the specimens, more than one third identified multiple owners, and another $11 \%$ were not sure who owned them. Of those who identified multiple owners in the survey $(n=28$; see Table 3$)$, the most popular combinations were Investigator \& Donor, Investigator \& Funder, and Investigator \& University. Thirteen respondents cited three or more owners. Although half the web survey sample $(n=40)$ identified a single owner, only 13 chose the university where the research is conducted - the owner typically 


\begin{tabular}{|l|l|}
\hline In your view, who owns the specimens used for this project? Check all that apply. \\
\hline$\Gamma$ & Principal Investigator (or Co-PI) \\
\hline$\Gamma$ & Co-Investigator \\
\hline$\Gamma$ & Other member of the research team \\
\hline$\Gamma$ & Funder or sponsor $^{1}$ \\
\hline$\Gamma$ & Individual donors $^{1}$ who contributed specimens \\
\hline$\Gamma$ & The University* $^{*}$ \\
\hline$\Gamma$ & Other (please fill in) \\
\hline$\Gamma$ & Not sure / Don't know \\
\hline *Specific university where all investigators were employed
\end{tabular}

Fig. 2. Ownership question from web survey. ${ }^{1}$ We used "donor" in our web survey. We prefer the term "specimen contributor" because of the inferences that come from the term donor, but when we pilot tested the web survey with biomedical researchers, respondents were confused by "specimen contributor" and urged us to use "donor" for clarity.

Table 2 Perceptions of ownership of specimen collection

\begin{tabular}{lcc}
\hline & Web survey & Follow-up interviews \\
\hline One owner & $40(50.00)$ & $4(33.33)$ \\
Two or more owners & $28(35.00)$ & $6(50.00)$ \\
Do not know who owns & $9(11.25)$ & $2(16.67)$ \\
Missing & $3(3.75)$ & $0(0.00)$ \\
Total & $80(100.00)$ & $12(100.00)$ \\
\hline
\end{tabular}

recognized in case law and by University policy. Thirteen identified a single investigator as sole owner (usually the principal investigator) and eight identified the specimen contributors ("donors" in the survey choices) as sole owners.

\section{Reasoning about ownership}

In the follow-up interviews, some respondents said they consulted their study consent form to see what, if anything, it said regarding ownership. Others reported that they based their answers on who they thought ought to own the specimens, for example, the individual because the specimen came from his/ her body or the principal investigator because s/he collected them, rather than referring to University policies or legal precedence. As in the pilot interviews, some respondents also changed their minds during the interview. Thus, the follow-up interviews further confirmed inconsistency and lack of consensus about specimen ownership.

\section{Sorting out rights, responsibilities, and ownership}

In both the pilot and follow-up interviews, respondents discussed rights and responsibilities associated with the specimens. Some investigators equated ownership of the specimens with the right to control them, which, depending on who or what the investigator believed to own the specimens, included (1) the right to withdraw the specimens, (2) the ability to conduct future research using them, (3) the right to distribute and manage them, (4) the authority to decide what tests are run on them, and (5) the right to destroy them (or have them destroyed in the case of subjects wishing to withdraw from studies). September 2010 Office for Human Research Protections guidance recommends that for human subjects' research involving minimal risk investigators may plan to retain and analyze data already collected at the time of withdrawal, provided subjects are informed during the initial informed consent process of the policy of the particular study regarding retention of data. ${ }^{28}$ The Office for Human Research Protections guidance does not address withdrawal or destruction of specimens. One investigator stated that ownership means "The ability to use these specimens for other projects in the future" and, thus, concluded that he owned the specimens. Others were reluctant to say that they owned the specimens but felt that the rights they had to the samples implied they owned them. As one noted, “...I guess I do own them in the sense that I can send them to somebody else with the right permission. I can destroy them. I can use it for doing tests on them. So, I guess I do own them. More than anybody else owns them."

Respondents who felt that the investigator owns, or ought to own, the specimens talked about the significant responsibilities associated with caring for the specimens, including the responsibility to ensure (1) their ethical management, (2) their proper maintenance and security, and (3) the funding to store the specimens after the completion of the study. One investigator, whose survey response was that both he and the contributors owned the specimens, noted that "ownership means the authority to determine what happens to [the specimens]." He remarked:

"First and foremost I think the donor owns the specimen .... The donor at any time can ask to be removed and that is their right to ask for those samples to be destroyed at any time that they want, so that's why technically they hold the trump card. The second person who is responsible is the principal investigator because ... you are the person who's bearing the responsibility and the liability for the possession of those samples."

In reasoning through this sort of hierarchical order of ownership, he discusses rights associated with the samples but then turns to responsibilities to justify why he, the principal investigator, has an ownership claim. However, on further reasoning, he ultimately seems to view his position as one of caretaking rather than ownership: "If I could only pick one answer I would say the donors who contributed are the owner .... However, I do think that I have an ethical obligation to care what happens to the samples." Based on this reasoning, he then argued strongly against placing ownership - that is, the rights and responsibilities associated with the specimens - in the hands of the University_ " "some University entity just takes charge of something that they don't even really know about themselves. I think the individual who donated should be the one who determines what happens."

\section{University as owner}

In the follow-up interviews, those who had answered in the web survey that the University owns the samples said that they chose this response because they (1) believed there to be some legal precedent, (2) checked the consent form, or (3) made an analogy to the University owning all supplies purchased with grant money. One respondent who chose the University as owner on the survey still indicated some uncertainty regarding ownership during the follow-up interview:

"Looking back ... I struggled with this (question) a little bit from the standpoint of I guess what was meant by ownership, and ultimately when you-any research that's done on this campus is not done in isolation of the 
Table 3 Single and multiple owners according to web survey respondents $(n=68)$

\begin{tabular}{|c|c|c|c|c|}
\hline One owner $(n=40)$ & Two owners $(n=15)$ & Three owners $(n=9)$ & Four owners $(n=2)$ & Five owners $(n=2)$ \\
\hline $\begin{array}{l}\text { One investigator (13) } \\
\text { University (13) } \\
\text { Donor (8) } \\
\text { Funder (3) } \\
\text { Clinic (2) } \\
\text { Registry (1) }\end{array}$ & $\begin{array}{l}\text { Investigator and donor (4) } \\
\text { Investigator and funder (3) } \\
\text { Investigator and university (3) } \\
\text { Two investigators (1) } \\
\text { Donor and registry (1) } \\
\text { Donor and university (1) } \\
\text { University and funder (1) } \\
\text { Two universities (1) }\end{array}$ & $\begin{array}{l}\text { Three investigators }{ }^{a}(2) \\
\text { Two investigators and } \\
\text { funder (2) } \\
\text { Two investigators and } \\
\text { university (2) } \\
\text { Investigator, donor and } \\
\text { university (1) } \\
\text { Investigator, university } \\
\text { and funder (1) } \\
\text { Two investigators and } \\
\text { donor (1) }\end{array}$ & $\begin{array}{l}\text { Investigator, donor, university, } \\
\text { and funder (1) } \\
\text { Two investigators, university, } \\
\text { and funder (1) }\end{array}$ & $\begin{array}{l}\text { Three investigators, }{ }^{a} \text { donor } \\
\text { and university (1) } \\
\text { Three investigators, }{ }^{a} \text { funder } \\
\text { and university (1) }\end{array}$ \\
\hline
\end{tabular}

${ }^{a}$ Three or more investigators may be more accurate, as the survey allowed up to three investigators to be indicated.

University. The University is ultimately responsible for I guess anything that's done on this campus."

The respondent added "I guess I really am unclear on who would own them ... I guess I would philosophically feel that the donors ultimately own the specimen from the standpoint that they could withdraw consent at any time."

This respondent had also consulted the study consent form for specification of ownership when he completed the survey, and referred to it during the interview, quoting: "Any blood, body fluids, or tissue specimens obtained for the purpose of the study become the exclusive property of the University." $\mathrm{He}$ stated that the IRB had provided that specific clause and "...as a PI with that standard language in, I felt that that must be an institutionalized decision."

Other investigators who identified the University as the owner in the survey said they did so with reluctance, typically due to their perceptions of their own close relationship to the samples or of the contributors' rights to have the samples destroyed. In response to "what makes someone or some organization the owner of the specimens?" one investigator described the conundrum this way:

“... we've had a lot of discussions around this, and I don't even know. I mean one day it's one thing, and one day it's the other. I guess if you're at liberty to distribute it and manage it, then I think you're probably owning it... We are the ones who ship it out and transfer it to other people and decide who legitimately should get it, and I think you pretty much own it then. I mean the institution that you work within I guess owns it because they're providing the infrastructure for all those things. The support of the staff and the finances for freezers and the whatever, without which you wouldn't be owning anything."

Another investigator who answered the survey by stating that the University owns the samples added an additional owner during the interview, "So I think in my verbal response I would broaden my single answer to say that the co-PIs own-that we own the sample."

\section{Alternative model?}

Like the aforementioned investigator who struggled with his sense of sample ownership, some investigators who acknowledged that they did not own the samples suggested an alternative relationship more in keeping with a stewardship model, which takes into account their responsibility to manage the specimens properly. One investigator affirmed that the University owns the samples but added that he is "the keeper." Another stated, 'I'm the steward. It's a national resource or a University resource. Kind of both, isn't it? But I don't own it. I have a responsibility to manage it properly." Finally, a respondent who indicated in the survey that he did not know who or what owned the specimens reasoned through the implications of ownership during the interview in this way:

"If I were assigned ownership of a collection of DNA samples, and I was killed, then there would be no owner, right? I mean then the samples would be subject to who knows what. So maybe the word owner is inappropriate. Maybe you should call them the custodian.... Because that suggests some level of responsibility."

\section{Retention of specimens}

Most investigators acknowledged that they had not thought about ownership of samples before our web survey and interviews. However, all claimed that the issue is important to understand as conflicts over ownership could impact their research work. The longer specimens are retained, the more likely such conflicts are to occur, as researchers move to new institutions, investigate new topics using the same specimens and data, share or combine their specimens with other collections, and make decisions about sample storage and destruction.

We asked survey respondents, "What will your research team do with some or all the specimens after this project is completed? (Check all that apply)" (Table 4). Although some respondents did not know $(n=11)$ or could not select a single category $(n=8)$, most responded that the research team would keep specimens, either permanently $(N=17)$ or for an as yet undetermined period $(N=29)$. Follow-up interviews explored investigators' decision-making process and perceptions of the advantages and disadvantages of retaining specimens, topics investigators found more familiar than ownership. Investigators described the value of retaining specimens in terms of the "infinite flexibility" they provided for future research, arguing that they would "never learn all they need to know and so [wouldn't] need this stuff anymore." For many, keeping specimens permanently or for a very long period was presumed, as "the default position," rather than formally decided: "You collect them because you expect they'll serve some useful purpose- that presumption never goes away."

Respondents did describe conditions under which samples would be destroyed, such as when requested by the contributor 
Table 4 Intentions to retain specimens

\begin{tabular}{lcc}
\hline & Web survey & $\begin{array}{c}\text { Follow-up } \\
\text { Interviews }\end{array}$ \\
$\begin{array}{l}\text { "We will destroy specimens at } \\
\text { a specified time" }\end{array}$ & $10(12.99)$ & $4(33.33)$ \\
$\begin{array}{l}\text { "We will return specimens to } \\
\text { the organization from which } \\
\text { we obtained them" }\end{array}$ & $2(2.60)$ & $0(0.00)$ \\
$\begin{array}{l}\text { "We will keep specimens } \\
\text { permanently" }\end{array}$ & $17(22.08)$ & $3(25.00)$ \\
$\begin{array}{l}\text { "We will keep specimens, but } \\
\text { have not decided for how } \\
\text { long" }\end{array}$ & $29(37.66)$ & $3(25.00)$ \\
$\begin{array}{l}\text { Not sure/do not know } \\
\text { Could not choose one category }{ }^{a}\end{array}$ & $\begin{array}{c}\text { 8 (10.39) } \\
\text { Total }\end{array}$ & $1(8.33)$ \\
$\begin{array}{l}{ }^{a} \text { Includes those who checked two categories (destroy and keep permanently } \\
\text { [depends on consent addendum], destroy and keep but do not know how long) and } \\
\text { those who provided text answers only. } \\
{ }^{b} \text { Three web survey respondents did not answer this question. }\end{array}$ \\
\hline
\end{tabular}

or when their research focus changed, and they described the heavy financial burdens related to maintaining and tracking specimens, costs often not covered by initial funders. Still, after weighing the burdens of keeping specimens versus destroying them, they seemed to always conclude that keeping them is more advantageous: "You would feel terrible if you had these precious specimens, and then destroyed them, and then read a paper in the literature that you could easily have tested with your specimens, and they're not there anymore."

\section{Little understanding of University policies}

In the web survey, open-ended comments suggested uncertainty or potential problems related to external policies about specimen ownership and retention. One survey participant wrote: "There is an incredible lack of knowledge and guidance for PIs about this issue. If the rules exist, nobody enforces them." We asked follow-up interview respondents about their awareness of and attitudes toward any policies related to ownership or retention of samples.

Respondents who thought there were University policies tended to abide by the policies - whatever they thought the policies were; they relied on the IRB for guidance about policies-again, whatever they thought that guidance was. Some respondents who had set a time to destroy specimens (e.g., 10 years after the completion of the study) did so because they thought it was required by the IRB. One, who reported that she was destroying her samples at the completion of her study because she believed that the IRB would not allow her to keep them, began to second guess her decision during the course of the interview. In fact, the University's IRB requires that investigators, in their applications for study approval, describe their plans for disposition of identifiable data or specimens. However, no policy determines what those plans should be, nor is there a policy dictating that plans be specified in consent forms.

Investigators who planned to keep the specimens indefinitely or who did not know how long they would keep the specimens generally did not reference University or IRB policies in the matter; nor did the University and/or the IRB seem to be part of their decision-making process. They assumed that if their IRB application was approved, then they were abiding by University policies. One noted, "There are so many rules and regulations out there that nobody can keep track of... I make the assumption that if I meet the IRB requirements and the HIPAA requirements, that I've probably done all that's reasonable." Another commented, "I think clearly the University has its policies that are expressed primarily through the IRB, and the IRB takes into account state and federal laws about that. So I don't have to think about that directly because it's included in what the IRB requires."

Investigators felt similarly about informed consent documents: if the documents were approved by the IRB, then their language must represent University policy. Consequently, several investigators consulted their own consent forms for language pertaining to ownership of the specimens to answer our survey question regarding ownership. Despite this, investigators also interpreted consent forms to suit their purposes, as when one investigator acknowledged that his consent form states that samples will be destroyed 10 years after the completion of the study but then added, "Who knows how long the study is going to last?" implying that there is actually great flexibility in determining when 10 years is over.

\section{DISCUSSION}

Although researchers share a common view that their samples are "precious," they do not display a set of shared perceptions about specimen ownership, retention, and oversight. Instead, investigators display widely divergent views on ownership of retained specimens, often identifying more than one owner, and show little awareness of University policies. Our interviews reveal the significant logistical and ethical implications associated with uncertainty about ownership and the desire to retain specimens long term or indefinitely. External funding opportunities for long-term proper maintenance and tracking of specimens is virtually nonexistent. Instead, these responsibilities often end up falling on the institution. Without proper funding, especially combined with the possibility that investigators' research interests may change or investigators may leave the university and their specimens behind, institutional obligations are unclear.

What rights and responsibilities attach to these long-held samples? Property law typically recognizes a "bundle of rights" associated with ownership. Rao ${ }^{29}$ highlights two of these rights as important to the debate over the goals of property law in the context of legal regulation of the human body - the right to control the property and the right to receive compensation. Characterizing ownership and the terms of use for the owned property, are critical issues for biospecimens, their associated data, and researchers who use them. Yassin and colleagues. ${ }^{30}$ propose that "custodianship" is more appropriate to describe the role of researchers and their institutions than "ownership." Other scholars prefer a "stewardship" model, similar to the role of a trustee. ${ }^{31}$ The hesitation many of the investigators in our interviews exhibit about ownership suggests that custodianship and stewardship frameworks deserve further exploration and development (see also discussion by Capron and colleages ${ }^{12}$ ).

These distinctions between ownership, custodianship, and stewardship of the specimens, any bundled set of rights to control or use them, and rights in commercial products that stem from research uses all remain subject to considerable debate. ${ }^{29,32,33}$ Winickoff $^{34}$ asserts that "bioethics scholarship on biobank governance has comparatively ignored property in favor of focusing on consent, IRBs, and privacy." Some policy leaders even acknowledge uncertainty regarding ownership: 
"The NCI has chosen to use the term 'custodianship' rather than 'ownership' in the context of human specimens because issues of ownership have yet to be resolved effectively in statute, regulation, or case law." ${ }^{35}$ Thus, definitional tensions persist regarding ownership of biospecimens for research.

Our empirical exploration of these issues has a number of limitations. It is based on interviews with investigators conducting genetic research with human samples in one US research university and, thus, cannot be generalized to other institutions or types of research. Despite attempts to systematically recruit respondents, selection bias may play a role in those who agreed to participate in both the pilot and follow-up interviews and in the web survey. Our questions may not have been appropriate for all study designs. For example, individual investigators involved in multisite studies, or studies mandated to participate in data sharing agreements, may be constrained in ownership or retention by external funding requirements. There may be other unknown factors that affected respondents' answers. Finally, our data illuminate ethical questions surrounding the indefinite retention of samples only as they relate to ownership, rather than subject protection (e.g., reconsenting subjects for new research and preventing identification of research subjects).

Despite these limitations, we have confidence in the themes revealed by our data. By using a mixed method study design, we were able to assess the prevalence of intriguing results from our pilot interviews and then follow-up on findings from the web survey. Exact numbers in response categories will not generalize to other populations, but these themes resonate throughout the data: (1) each data source revealed significant inconsistency in views about who actually owns the specimens; (2) investigators desire to retain and store "precious specimens" for "infinite flexibility"; (3) norms of ownership are not seen by investigators as officially codified in any transparent or mutually agreed-upon fashion. We suspect that these findings are common among investigators in other academic institutions.

Although the ethical, legal, and social landscape of specimen ownership is still evolving, our research findings have clear policy implications for the present. Those exercising direct control over human research specimens should be better informed about policies regarding ownership and retention and work nationally with interdisciplinary groups to explore the concerns and needs of all stakeholders in the biobanking enterprise. Ideally, investigators should have guidance regarding how to safeguard samples if there is a significant change in oversight, such as a principal investigator moving to another institution or leaving research. In an era of increasing pressure for investigators to deposit research specimens and data in widely accessible repositories or databases, it is important to acknowledge and address the ethical obligations investigators feel toward specimen contributors. In the absence of clearly agreed-upon professional norms governing collection, use, ownership, and storage of human biologic specimens, the rights of stakeholders and the proper conduct of research may be impeded. Thus, further research is needed to assist in establishing and disseminating clear and feasible guidelines for ownership and retention of genetic material and data.

\section{ACKNOWLEDGMENTS}

This research is supported by grant number P50HG004488 from the National Human Genome Research Institute. The content is solely our responsibility and does not necessarily represent the official views of the National Human Genome Research Institute or the National Institutes of Health. The authors thank Wendell Fortson, Kriste Kuczynski, and Warren Whipple for their valuable contributions to this study.

\section{REFERENCES}

1. Eiseman E, Haga S. Handbook of human tissue sources: a national resource of human tissue samples. Santa Monica, CA: RAND Corporation, 1999.

2. Office for Human Research Protections. Guidance on research involving coded private information or biological specimens. Available at: http:// www.hhs.gov/ohrp/policy/cdebiol.html. Accessed January 12, 2011.

3. Kaiser J. Biomedical research: court decides tissue samples belong to university, not patients. Science 2006;312:346.

4. Skloot R. The immortal life of Henrietta Lacks. New York: Crown, 2010

5. Allen MJ, Powers MLE, Gronowski KS, Gronowski AM. Human tissue ownership and use in research: what laboratorians and researchers should know. Clin Chem 2010;56:1675-1682.

6. Moore v. Regents of the Univ. of California, 793 P.2d 479 (Cal. 1990).

7. Greenberg v. Miami Children's Hospital, 264 F.Supp.2d 1064 (S.D. Fla. 2003).

8. Washington Univ. v. Catalona, 437 F.Supp.2d 985 (E.D. Missouri 2006).

9. Havasupai Tribe v. Arizona Board of Regents, 204 P.3d 1063 (Ariz. Ct. App. 2008).

10. Harmon A. Indian tribe wins fight to limit research of its DNA. The New York Times. April 22, 2010:A1.

11. Hens K, Nys H, Cassiman JJ, Dierickx K. Genetic research on stored tissue samples from minors: a systematic review of the ethical literature. Am J Med Genet A 2009;149A:2346-2358.

12. Capron AM, Mauron A, Elger BS, Boggio A, Ganguli-Mitra A, BillerAndorno N. Ethical norms and the international governance of genetic databases and biobanks: findings from an international study. Kennedy Inst Ethics J 2009;9:101-124.

13. Bryant RJ, Harrison RF, Start RD, et al. Ownership and uses of human tissue: what are the opinions of surgical in-patients? J Clin Pathol 2008;61:322-326.

14. Wolf LE, Catania JA, Dolcini MM, Pollack LM, Lo B. IRB chairs' perspectives on genomics research involving stored biological materials: ethical concerns and proposed solutions. J Empirical Res Human Res Ethics 2008;3:99-111.

15. Hakimian R, Korn D. Ownership and use of tissue specimens for research. JAMA 2004;292:2500-2505.

16. Catalona WJ. Ownership and use of tissue specimens for research. Comment on: JAMA 2004;292:2500-2505. JAMA 2005;293:1325; author reply 1325-1326.

17. Björkman B. Different types-different rights. Distinguishing between different perspectives on ownership of biological material. Sci Eng Ethics 2007;13:221-233.

18. Björkman B, Hansson SO. Bodily rights and property rights. $J$ Med Ethics 2006;32:209-214.

19. Bovenberg J. Whose tissue is it anyway? Nat Biotechnol 2005;23:929-934.

20. Charo RA. Body of research-ownership and use of human tissue. $N$ Engl J Med 2006;355:1517-1519.

21. Dry S. Who owns diagnostic tissue blocks? Lab Med 2009;40:69-73.

22. Quigley M. Property and the body: applying Honore. J Med Ethics 2007; 33:631-634

23. Ness RB, American College of Epidemiology Policy Committee. Biospecimen "ownership": point. Cancer Epidemiol Biomarkers Prev 2007;16:188-189.

24. Dressler LG. Biospecimen. "ownership": counterpoint. Comment on: Cancer Epidemiol Biomarkers Prev 2007;16:188-189. Cancer Epidemiol Biomarkers Prev 2007;16:190-191.

25. Qualtrics Labs, Inc. Qualtrics. Provo, UT: Qualtrics Labs, Inc., 2008.

26. StataCorp. Stata Statistical Software: Release 10. College Station, TX: StataCorp LP, 2007.

27. Hsieh H-F, Shannon SE. Three approaches to qualitative content analysis. Qual Health Res 2005; 15:1277-1288.

28. Office for Human Research Protections. Guidance on withdrawal of subjects from research: data retention and other related issues. Available at: http:// www.hhs.gov/ohrp/policy/subjectwithdrawal.pdf. Accessed January 12, 2011

29. Rao R. Genes and spleens: property, contract, or privacy rights in the human body? J Law Med Ethics 2007;35:371-382.

30. Yassin R, Lockhart N, González del Riego M, et al. Custodianship as an ethical framework for biospecimen-based research. Cancer Epidemiol Biomarkers Prev 2010;19:1012-1015.

31. Fullerton SM, Anderson NR, Guzauskas G, Freeman D, Fryer-Edwards K. Meeting the governance challenges of next-generation biorepository research. Sci Transl Med 2010 20;2:15cm3.

32. Janger EJ. Genetic information, privacy, and insolvency. J Law Med Ethics 2005;33:79-88.

33. Glantz L, Roche P, Annas GJ. Rules for donations to tissue banks - what next? N Engl J Med 2008;358:298-303

34. Winickoff DE. Partnership in UK Biobank: a third way for genomic property? J Law Med Ethics 2007;35:440-456.

35. National Cancer Institute, Office of Biorepositories and Biospecimen Research. Custodianship and ownership issues in biospecimen research. SymposiumWorkshop. Available at: http://biospecimens.cancer.gov/resources/publications/ workshop/cow.asp. Accessed November 1, 2010. 